\title{
Tonsillar Cyst
}

National Cancer Institute

\section{Source}

National Cancer Institute. Tonsillar Cyst. NCI Thesaurus. Code C82893.

A cystic structure in the tonsillar tissue. 